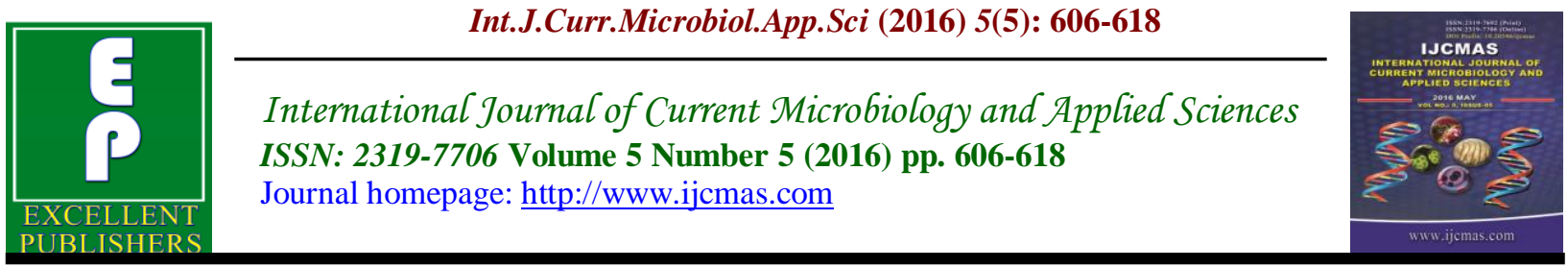

Review Article

http://dx.doi.org/10.20546/ijcmas.2016.505.062

\title{
Isolation of Actinomycetes: A Complete Approach
}

\author{
Ravi Ranjan Kumar* and Vasantba J. Jadeja \\ Department of Biotechnology, Shree M. \& N. Virani Science Collage, \\ Kalawad Road, Rajkot, Gujarat-360005, India \\ Department of Microbiology, Shree M. \& N. Virani Science Collage, \\ Kalawad Road, Rajkot, Gujarat-360005, India \\ *Corresponding author
}

\section{Keywords}

Actinomycetes, antibiotics, isolation methods, Enrichment

\section{Article Info}

Accepted: 18 April 2016 Available Online: 10 May 2016

\section{A B S T R A C T}

Actinomycetes have provided many industrially important bioactive compounds having great economic importance and always being a curious organism for secondary metabolite production. Actinomycetes have long been recognized as prolific producers of enzymes, antibiotics, anti cancerous agents and play important role in recycling of organic matter. Numerous methods have been advocated for isolation of actinomycetes to facilitate the discovery of natural compounds specially antibiotics. Isolation of actinomycetes can fulfill all the novel essentialities associated with actinomycetes. Actinomycetes are widely distributed in the natural habitats, hence various methods like pretreatments, enrichment, combinations of antibiotics, specific isolation media and some novel methods has been adapted for isolation. Marine actinomycetes were also isolated by various methods and found to be important source for novel secondary metabolites. Rare actinomycetes isolated by providing combinations of methods or high throughput screening methods. Endophytic actinomycetes can be isolated by mostly chemical treatment for surface sterilization followed by serial dilution. Strategy for a range of isolation methods have been mentioned in this review for discovery of various genera of actinomycetes.

\section{Introduction}

Microbial secondary metabolites continue to be a chemically diverse source for the discovery and development of pharmaceutical agents and also biochemical probes to study human disease processes (Tamotsu Furumai et al., 2001). A large number of actinomycetes have been isolated and screened from soil in the past several decades, accounting for $70-80 \%$ of relevant secondary metabolites available commercially (Yasuhiro et al., 2002). Actinomycetes are filamentous, branching gram positive bacteria with a fungal type of morphology which are potent source for the production of novel antibiotics accounts for more than $50 \%$ of the known antibiotics discovered till date. Antibiotics play a crucial role in the development of tissue culture techniques and basic screenings, primarily in biochemistry, molecular biology, microbiology and genetics and to a 
lesser extent, pharmacology and organic chemistry (Nanjwade et al., 2010). Actinomycetes are considered to be microbiological curiosities of no great economic importance, have become the subjects of intensive searches for sources of new, biologically active compounds. Actinomycetes are dominantly present in soil but also ubiquitous in the natural habitats which facilitate a new hope that diverse group of actinomycetes can be isolated in search of novel metabolites.

Marine environments were recently found to be one of the important sources for the isolation of new actinomycetes with potentiality to produce chemically diverse compounds with a wide range of biological activities (Bredholt et al., 2008). The endophytic actinomycetes which are associated with plants also play important role in protection of their host from phytopathogenic invasions (Crawford et al., 1993). Several endophytic actinomycetes act as plant growth promoter by producing of phytohormone, indole-3- acetic acid, iron chelating molecules and siderophores (Indananda et al., 2011)

Discovery of novel microbial metabolites from actinomycetes can be enhanced by isolating diverse group of actinomycetes. Acquiring new strains is a challenging condition for actinomycetes resource development, and therefore, novel separation methods tended to be very critical. Various isolation methods have been used earlier for different genera of actinomycetes and some novel methods has been applied in recent year. Hayakawa and Nonomura developed various methods for isolating desirable rare actinomycetes genera from natural habitats. These methods include a variety of pretreatment techniques in combination with enrichment techniques that appropriately supplement agar media with selective antibacterial agents (Hayakawa et al., 2008). Further novel methods had been applied for isolation of rare and uncommon actinomycetes. Here in this review, we tried to explore improved methodologies for isolation of various genera of actinomycetes from soil, marine and plants.

\section{Bacterial Isolation Methods}

Actinomycetes are gram positive bacteria utilize both simple and complex substrate for their growth. General bacterial isolation methods like serial dilution to reduce overcrowd, pour plate, streaking and centrifugation techniques are also applicable for isolation of actinomycetes. Centrifugation of soil sample followed by serial dilution of supernatant can enhance the chances of actinomycetes growth on plate (Rehacek, 1959). But none of these methods can selectively isolate actinomycetes and hence, purification of actinomycetes is difficult task.

\section{Selective Isolation Methods}

Non-actinomycetes bacteria prevent the growth of actinomycetes as a pure culture and hence, selective isolation of actinomycetes was developed using six approaches: (i) nutritional selection, where media are formulated with nutritional components, which are preferentially utilized by actinomycetes, (ii) selective inhibition, in which inhibitors such as antifungal agents and antibiotics are incorporated to inhibit non-actinomycetes bacteria, (iii) Pretreatment of sample, in which soil, marine sample or plant parts were treated with physical or chemical method in order to decrease the number of non-actinomycetes bacteria or fungi, (iv) Enrichment method, in which nutrient media can be enriched with certain additional 
supplements, which favors the growth of actinomycetes or inhibit the growth of other microbes, (v) Membrane filter method, which does not dependent upon pretreatment, specific media or antibiotics, and (vi) Integrated method, in which any combination of different approaches can be applied.

\section{Nutritional Selection}

Several carbon, nitrogen and complex substances have been considered as selective substrates for actinomycetes. Selective media were always preferred for isolation of actinomycetes because sample contains other genera of microorganisms. So, isolation media must be design to reduce the development of competing microbes without adversely affecting actinomycetes propagules (Cross et al., 1982, Goodfellow et al., 1989). Protein and amino acids as a nitrogen sources, play very crucial role in the differential isolation of actinomycetes. The use of $\mathrm{L}$ arginine as a selective nitrogen source favoring actinomycetes over bacteria was reported by Porter, Wilhelm \& Tresner (1960) and El Nakeeb \& Lechevalier (1963). Kuster \& Williams (1964) examined several carbon and nitrogen sources, concluded that starch (or glycerol), casein, nitrate were the most selective mixture. L-arginine can be replaced by glycine for non-Streptomyces actinomycetes. Use of chitin as a sole carbon and nitrogen source was recommended by Lingappa \& Lockwood (1962). Several selective media like humic acid vitamin agar, Kuster's agar, starch casein agar, actinomycetes isolation agar, starch nitrate agar, inorganic salt starch agar, glycerol glycine agar, chitin agar is popular for specific isolation of actinomycetes. Zhang recommended Trace salt solution, soil extracts agar, Glycerol-asparagine agar, Gause's No.1 medium, Complex HV agar, Zhang's starch soil extract agar were recommended for improved isolation of actinomycetes.

\section{Selective Inhibition}

Many workers have used antibiotics in media to achieve selective inhibition of various groups of organisms. The use of antifungal antibiotics to improve the efficiency of media for isolating bacteria has been reported. Fungi were able to grow with actinomycetes and hence antibiotics which inhibit fungi have been found particularly useful in studies on actinomycetes. Actidione (cycloheximide) has been used by Dulaney, Larsen \& Stapley (1955), Corke \& Chase (1964)) Corbaz, Gregory \& Lacey (1963) and Porter et al., (1960) recommended nystatin and pimaricin as a potent antifungal agent.

Most antibacterial antibiotics inhibit actinomycetes along with other bacteria which lead to difficulty in suppression of bacteria while allowing growth of actinomycetes. Dulaney et al., (1955) recommended a mixture of antibacterial and antifungal antibiotics to allow selective development of actinomycetes. Nalidixic acid can inhibit growth of gram negative bacteria and some gram positive bacteria, recommended for isolation of soil actinomycetes. Nalidixic acid and cycloheximide inhibits most of the gram negative bacteria and fungi and can applicable for isolation of various genera of actinomycetes (Ravi et al., 2015). To successfully eliminate bacterial and fungal contaminants, media was supplemented with synthetic antibacterial agents, nalidixic acid, trimethoprim, tunicamycin, leucomycin, faridomycin, kanamycin, chlortetracycline etc. Hopwood et al., (1985) was the first to produce new antibiotics, so called hybrid antibiotics, by interspecies cloning. Subsequently, the hybrid technique has been 
successfully applied to producing modified products in other Streptomyces species (McAlpine et al., 1987, Epp et al., 1989, Strohl et al., 1989).

\section{Pretreatment of Sample}

Pre-treatment of soil can stimulates the isolation of actinomycetes by either promoting growth of actinomycetes or eliminating most unwanted gram negative bacteria (Matsukawa et al., 2007 and Hong et al., 2009). Various pretreatment techniques have been developed for different genera of actinomycetes. In natural habitats, Streptomycetes are common and are usually a major component of the total actinomycetes population (Hayakawa, 2008). Streptomycetes can be easily isolated by physical pretreatment methods, but to isolate other than Streptomycetes, chemical or combinations of physical and chemical methods are used.

\section{Physical Treatments}

Physical treatment such as moist incubation using radiation, glycerol, air dry, dry heat, centrifugation, cellulose infiltration, pollen baiting followed by drying are commonly applied for different genera of actinomycetes. Spores of actinomycetes are more resistance to desiccation as compared to gram negative bacteria and hence, heat dry of soil sample at $120 \mathrm{oc}$ for 1 hour favors growth of Streptomyces and other rare genera including Spirilliplanes, Actinomydura, Microbispora, spirilliplanes etc on humic acid vitamin (HV) agar (Hayakawa et al., 1991a, Tamura et al., 1997). Agate \& Bhat (1963) attempted suppression of bacteria and fungi by preincubation of soil at $110^{\circ} \mathrm{c}$ for $10 \mathrm{~min}$. Nocardia speies was selectively isolated by Yamamura et al., using sucrose gradient centrifugation (Yamamura et al., 2005).
Preferential isolation of motile actinomycetes can be done by centrifugation which eliminates Streptomycetes and other non-motile actinomycetes and facilitates motile actinomycetes, retained in the supernatant and can be spread on appropriate medium containing nalidixic acid and trimethoprim (Hayakawa et al., 2008).

Selective isolation of actinomycetes was also favored by radiation (Bredholdt et al., 2007). Super-high frequency irradiation favors isolation of Streptosporangium and Rhodococcus species, Extremely high frequency irradiation was effective for Streptosporangium spp., Nocardiopsis, Nocardia and UV-irradiation was suitable for isolation of Nocardiopsis and Pseudonocardia spp.

\section{Chemical Treatments}

Chemicals treatments such as Calcium carbonate and chitin treatment, calcium chloride, Phenol, SDS, yeast extract, Germicide, Chemotactic agents, and Chloramine- $T$ can be used for selective isolation of actinomycetes. Calcium carbonate and chitin acts as carbon and nitrogen source, support growth of actinomycetes. Tsao, Leben \& Keitt (1960) reported increased selective development of actinomycetes when air-dried soil was remoistened, mixed with calcium carbonate and incubated at $28^{\circ} \mathrm{c}$ temp. Lechevalier (1963) found that the calcium carbonate treatment gave highest colony counts, while the centrifugation and phenol treatments gave counts lower than those from untreated suspensions. Soil sample treated with SDS $0.05 \%$ and yeast extract $5 \%$ favors growth of Streptomycetes and other genera on nalidixic acid contain HV agar (Hayakawa et al., 1989). Micromonospora and Streptomyces violaceusniger can be 
selectively isolated by $1.5 \%$ phenol treatment to the soil sample (Hayakawa et al., 2004 and 1991a). Treatment of soil suspensions with a $1.4 \%$ (w/v) phenol solution was recommended by Lawrence (1956). Soil sample treated with chloramine$\mathrm{T}$ was found to promote the growth of Herbidospora, Microbispora, Microtetraspora, Nonomuraea and Streptosporangium on nalidixic acid contain HV agar (Hayakawa et al., 1997).

\section{Physical and Chemical Treatment}

A combination of physical and chemical treatment was found to be more suitable method effectively isolate various genera of actinomycetes. Dry heat of soil sample at 110 oc for 1 hour and treatment with $1 \%$ phenol favors isolation of Actinomadura viridis on kanamycia, josamycin, lysozyme and nalidixic acid contaning $\mathrm{HV}$ agar (Hayakawa et al., 1995a). Dry heat of soil sample at $120 \mathrm{oc}$ for 1 hour and $1.5 \%$ phenol promotes Microbispora on nalidixic acid contain HV agar (Hayakawa et al., 1991a). Dry heat at $120 \mathrm{oC}$ to the soil sample along with $0.01 \%$ benzethonium chloride favors Streptosporangium or Dectylosporangium genera on nalidixic acid and leucomycin contain HV agar (Hayakawa et al., 1991b). Dry heat treatment of soil sample at 110 oc for 1 hour along with $0.05 \%$ benzethonium chloride supports Microtetraspora on kanamycin, naladixic acid and norfloxacin contain LSV-SE agar (Hayakawa et al., 1996b). Sucrose gradient method followed by $\mathrm{HV}$ agar enriched with nalidixic acid supports growth of Nocardia (Yamamura et al., 2003).

\section{Enrichment Treatment}

Diverse genera of actinomycetes isolation have been increased using addition of nutritional or non-nutritional ingredient for the purpose of selective isolation. Enrichment is one of the successful methods in terms of diversity and abundance culturable bacteria. An improved chemotactic method developed by Hayakawa et al., (1991c) utilize the strong chemotactic response of actinomycetes zoospores to $\gamma$-collidine and shows increased recovery of Actinoplanes spp. and Dactylosporangium spp. from various soil samples. Thermophilic actinomycetes were specifically isolated by phage susceptibility of thermophilic actinomycetes provided a selective means of reducing their numbers on isolation plates; which increased the numbers of Thermomonospora, Saccharopolyspora rectivirgula, and thermophilic Streptomyces spp. (Kurtboke et al., 1993).

A coal-vitamin medium was developed by Kyun man; in which number of actinomycetes had been increased and growth of other soil bacteria inhibited. The pretreatment of soil suspension with peptone $(6 \%)$ and lauryl sulfate $(0.05 \%)$ at $50^{\circ} \mathrm{C}$ for $10 \mathrm{~min}$, also greatly increased the number of actinomycetes from soil prior to incubation with new medium. Differential centrifugation was performed by Antonie Van Leeuwenhoek in 2000 for selective isolation of motile actinomycetes in soil and plant litter.

Rehydration and centrifugation (RC) method was developed by Hayaka et al., for selective isolation of diverse zoosporic actinomycete genera (Actinokineospora, Catenuloplanes and Kineosporia directly from soil and plant litter. The centrifugation stage greatly eliminated Streptomycetes and other non-motile actinomycetes from the liquid phase, thereby facilitating selective growth of rare, motile actinomycetes on the isolation plates subsequent to inoculation. 


\section{Membrane Filter Method}

Membrane filter method was described by Hirsch for selective isolation of filamentous actinomycetes from natural mixed microbial populations without relying upon specific media and antibiotics. Nutrient agar medium supports the growth of mix bacterial cultures and also suitable for actinomycetes isolation. Overlay of nutrient agar medium with a 0.22 to $0.45 \mu \mathrm{m}$ pore size cellulose ester membrane filter followed by inoculation of filter surface with mix cultures and incubation allow the growth of bacteria. Actinomycetes posses highly branched mycelial networks and hence they have ability to penetrate the pores of membrane filter. During incubation, mycelium of actinomycetes penetrates the filter pores to the underlying agar medium, whereas growth of non-actinomycetes bacteria is restricted to the filter surface. Removal of membrane filter and incubation of agar medium allow the development of the isolated actinomycetes colonies (Hirsch $e t$ al., 1983)

\section{Integrated Method}

This is most preferred method for selective isolation of actinomycetes. A combination of physico-chemical method with suitable antibiotics and other selective method promotes desired growth of actinomycetes. Primary treatment of soil with calcium carbonate applied on selective medium containing nalidixic acid shown tremendous increase in the number of the actinomycetes isolated as pure cultures (Alferova et al., 1989).

Pollen-baiting and drying method using humic acid vitamin agar with nalidixic acid specifically promotes the growth of Actinoplanes (Hayakawa et al., 1991d). Rehydration $\left(30^{\circ} \mathrm{c}, \quad 90 \quad \mathrm{~min}\right)$ and centrifugation $(1500 \times \mathrm{g}, 20 \mathrm{~min})$ of sample followed by humic acid vitamin agar with nalidixic acid and trimethoprim supports growth of Actinoplanes, Actinokineospora, Actinosynnema, Catenuloplanes, Cryptosporangium, Dactylosporangium, Geodermatophilus, Kineosporia and Sporichthya.

$\mathrm{CaCO}_{3}$, rehydration and centrifugation method were integrated and HV agar with fradiomycin, kanamycin, trimethoprim, nalidixic acid antibiotics were used by Otoguro et al., in 2001 for the enrichment and selective isolation of Actinokineospora spp. in soil and plant litter. Diverse rhizoplane streptomycetes with high levels of anti-phytopathogenic activity were efficiently isolated from healthy herbaceous plants using moist incubation and desiccation (MI\&D) method (Hayaka et al., 2007).

\section{Isolation of Actinomycetes from Marine}

Marine actinomycetes also provided some valuable bioactive compounds and hence increasing curiosity for isolation from diverse sources. Many studies have been done on the isolation of actinomycetes from marine sediments (Barcina et al., 1987, Goodfellow et al., 1983) and Lechevalier et al., (1970). However some of the strategies have been specifically used for selective isolation of marine actinomycetes including (i) Seawater based media were used for the isolation of first obligate marine genus Salinispora (Maldonado et al., 2005a). (ii)Slightly acidic conditions affect greater diversity of actinomycetes than neutral water (Goodfellow and Williams, 1983 and Ramesh et al., 2009). (iii) Heat treatment of marine sediments at $50^{\circ} \mathrm{C}$ for $60 \mathrm{~min}$ followed by dilution with sterile $0.5 \%$ saline and application of cycloheximide along with nystatin increases diverse marine 
actinomycetes (Russell et al., 1993). (iv) Several heat treatment and serial dilution method has been shown in the Table1.

(v) Various kinds of radiation (Bredholt et al., 2008) favor differential isolation of actinomycetes genera, for example, Streptosporangium and Rhodococcus species isolated by SHF (super-high frequency) irradiation; Nocardiopsis, Nocardia and Streptosporangium spp are effectively grown by EHF (extremely high frequency) irradiation and UV-irradiation was effective for isolation of Nocardiopsis, Nocardia and Pseudonocardia spp. (vi) various modifications of growth media and end-point dilution methods using microtitre dish plate formats that allowed the cultivation of the ubiquitous marine bacterial (Bredholt et al., 2008) (vii) unique enrichment procedures (Magarvey et al.,
2004) (viii) culture-independent methods (Mincer et al., 2005) (ix) construction of environmental genomic libraries (Donadio $e t$ al., 2002) (x) digital image analysis (Velho et al., 2010). Micromonospora (Bull et al., 2005), Streptomyces (Moran et al., 1995), Nocardia, Rhodococcus and Dietzia (Rainey et al., 1995 , Heald et al., 2001), Prauserella (Kim et al., 1999), Serinicoccus (Yi et al., 2004, Xiao et al., 2011), Salinispora (Jensen et al., 2005a, Maldonado et al., 2005a), Lamerjespora (Fortman et al., 2005), Marinospora (Jensen et al., 2005b, Kwon et al., 2006), Salinibacterium (Han et al., 2003), Aeromicrobium (Bruns et al., 2003), Williamsia (Stach et al., 2004), Verrucosispora (Riedlinger et al., 2004), Marinactinospora (Tian et al., 2009b) and Sciscionella (Tian et al., 2009a) has been isolated using various method from the marine environment.

Table.1 Summary of Methods Developed for the Isolation of Actinomycetes from Marine

\begin{tabular}{|c|c|c|c|c|}
\hline $\begin{array}{l}\text { Isolation } \\
\text { sample } \\
\text { collection from }\end{array}$ & Pretreatment & Culture media & Genera selected & Reference \\
\hline $\begin{array}{l}\text { Mangrove } \\
\text { sediments of } \\
\text { Andaman and } \\
\text { Nicobar Islands, } \\
\text { India } \\
\end{array}$ & $\begin{array}{l}\text { Dry heat treatments: } \\
55^{\circ} \mathrm{C} \text { for } 5 \mathrm{~min} \text { and } \\
60 \mathrm{~min} \text {, } \\
70^{\circ} \mathrm{C} \text { for } 15 \mathrm{~min} \text { and } \\
100^{\circ} \mathrm{C} \text { for } 1 \mathrm{hr}\end{array}$ & $\begin{array}{l}\text { Kuster's agar, } \\
\text { Starch casein agar, } \\
\text { Actinomycetes } \\
\text { isolation agar }\end{array}$ & Streptomyces spp. & $\begin{array}{l}\text { (Hayakawa et } \\
\text { al.,1987, } \\
\text { Hayakawa et al., } \\
\text { 1991, Seong et al., } \\
\text { 2001) } \\
\end{array}$ \\
\hline $\begin{array}{l}\text { Otsuchi } \\
\text { Bay in Iwate }\end{array}$ & $\begin{array}{l}\text { Dried overnight at } \\
27^{\circ} \mathrm{C}\end{array}$ & $\begin{array}{l}\text { Starch nitrate agar } \\
\text { and } \\
\text { HV agar with } \\
\text { cycloheximide and } \\
\text { nalidixic acid }\end{array}$ & $\begin{array}{l}\text { Micromonospora } \\
\text { globosa }\end{array}$ & $\begin{array}{l}\text { (Chiaki et al., } \\
\text { 2007) }\end{array}$ \\
\hline $\begin{array}{l}\text { Bigeum Island, } \\
\text { South West } \\
\text { coast of South } \\
\text { Korea }\end{array}$ & $\begin{array}{l}\text { Sonication for 5-10 } \\
\text { min }\end{array}$ & $\begin{array}{l}\text { starch casein agar } \\
\text { with cycloheximide } \\
\text { and nalidixic acid }\end{array}$ & $\begin{array}{l}\text { Streptomyces } \\
\text { hygroscopicus }\end{array}$ & $\begin{array}{l}\text { (Parthasarathi et } \\
\text { al., 2012) }\end{array}$ \\
\hline $\begin{array}{l}\text { Netritic zone in } \\
\text { the sea around } \\
\text { Japan }\end{array}$ & $\begin{array}{l}\text { Heat treatment: Add } \\
0.1 \mathrm{ml} \text { saline } \\
\text { solution and heated } \\
55^{\circ} \mathrm{C} \text { for } 30 \mathrm{~min}\end{array}$ & $\begin{array}{l}\text { ISP-4 medium with } \\
\text { nalidixic acid and } \\
\text { cycloheximide and } \\
\text { various } \\
\text { concentration of } \\
\mathrm{NaCl}\end{array}$ & $\begin{array}{l}37 \% \text { of } \\
\text { Streptomyces and } \\
26 \% \text { of } \\
\text { Micromonospora }\end{array}$ & $\begin{array}{l}\text { (Chiaki et al., } \\
\text { 2010) }\end{array}$ \\
\hline $\begin{array}{l}\text { coastal region } \\
\text { of Tamil } \\
\text { Nadu,India }\end{array}$ & $\begin{array}{l}\text { Serial dilution } \\
\text { method }\end{array}$ & Starch casein agar & Streptomyces spp. & $\begin{array}{l}\text { (Deepika et al., } \\
\text { 2009b) }\end{array}$ \\
\hline
\end{tabular}


Table.2 Summary of Methods Developed for the Isolation of Endophytic Actinomycetes

\begin{tabular}{|c|c|c|c|c|}
\hline $\begin{array}{l}\text { Isolation sample } \\
\text { collection from }\end{array}$ & Pretreatment & Culture media & Genera selected & Reference \\
\hline $\begin{array}{l}\text { Nagano, } \\
\text { Shizuoka and } \\
\text { Yamanashi } \\
\text { prefectures, } \\
\text { Japan }\end{array}$ & $\begin{array}{l}\text { Moist incubation and } \\
\text { desiccation (MI \& D) } \\
\text { method }\end{array}$ & HV agar & $\begin{array}{l}\text { Streptomyces, } \\
\text { Actinoplanes, } \\
\text { Micromonospora, } \\
\text { Nocardia }\end{array}$ & $\begin{array}{l}\text { (Hayakawa } e t \\
\text { al., 2007) }\end{array}$ \\
\hline $\begin{array}{l}\text { Panyu town, } \\
\text { Guangzhou, } \\
\text { South } \\
\text { China }\end{array}$ & $\begin{array}{l}70 \% \text { ethanol for } 5 \\
\text { min., Sodium } \\
\text { hypochlorite for } 20 \\
\text { min., } 10 \% \mathrm{NaHCO}_{3}\end{array}$ & $\begin{array}{l}\mathrm{S} \text { agar with nalidixic } \\
\text { acid }\end{array}$ & $\begin{array}{l}\text { Streptomyces, } \\
\text { Streptoverticillium, } \\
\text { Nocardia, } \\
\text { Actinomadura, } \\
\text { streptosporangium } \\
\end{array}$ & $\begin{array}{l}\text { (Zhou } e t \\
\text { al.,2004) }\end{array}$ \\
\hline $\begin{array}{l}\text { Guanghou, South } \\
\text { China }\end{array}$ & $\begin{array}{l}10 \% \mathrm{NaHCO}_{3} \text { for } 10 \\
\text { min }\end{array}$ & $\begin{array}{l}\mathrm{S} \text { agar with nalidixic } \\
\text { acid }\end{array}$ & Streptomyces & $\begin{array}{l}\text { (Cao et al., } \\
\text { 2004) }\end{array}$ \\
\hline $\begin{array}{l}\text { Toyama and } \\
\text { Miyagi } \\
\text { prefectures, } \\
\text { Japan }\end{array}$ & $\begin{array}{l}70 \% \text { ethanol for } 2 \\
\text { minutes and } 1 \% \\
\mathrm{NaClO}_{4} \text { solution for } 5 \\
\text { minutes }\end{array}$ & $\begin{array}{l}\text { Bn-2 agar with } \\
\text { amphotericin B } \\
0.005 \% \text {, benomyl } \\
0.02 \% \text { and } \\
\text { cycloheximide } 0.005 \%\end{array}$ & $\begin{array}{l}\text { Streptomyces } \\
\text { galbus }\end{array}$ & $\begin{array}{l}\text { (Tamotsu et al., } \\
\text { 2002) }\end{array}$ \\
\hline
\end{tabular}

Recent techniques of isolation include various modifications of growth media and end-point dilution methods using microtitre dish plate formats that allowed the cultivation of the ubiquitous marine bacterial (Connon et al., 2002, Rappe et al., 2002, Giovannoni et al., 2005). Highthroughput cultivation is an innovative technique that mimics nature, eliminates undesired, fast-growing bacteria and creates suitable conditions for rare, slow-growing actinomycetes. High-throughput cultivation (HTC) technology that employs agarose microcapsules to encapsulate single cells directly from environmental samples has been developed.

Fluorescence-activated cell sorting (FACS) enables the discrimination of slow-growing microbes retained in the microcapsules from fast growing cells that overgrow and burst the microcapsule. This method has been suggested to be suitable for massively parallel cultivation of microorganisms for natural-product screening and drug discovery (Keller et al., 2004).

\section{Isolation of Endophytic Actinomycetes}

Endophytic actinomycetes have been explored in the recent years as a potent antibiotic producer. They can be isolated from the disinfected surfaces of plant tissues or that can be extracted from within the plant (Siva et al., 2011).

$70 \%$ ethanol and various concentration of sodium hypochloride for different time period have been recommended to remove surface microorganisms. $10 \% \quad \mathrm{NaHCO} 3$ solution used to disrupt the plant tissues and to inhibit the growth of fungi (Shining Zhou et al., 2003). To suppress the growth of non Streptomycetes bacteria nalidixic acid is also used with media (Cao et al., 2004). Other than surface sterilization method an enrichment method moist incubation and desiccation is used for isolation of endophytic actinomycetes (Table 2).

\section{Conclusion}

Antimicrobial resistance is a global problem 
which demands for novel antimicrobial structure against pathogenic microbes. Actinomycetes are famous for antibiotic production and continued to be explored in hope of getting novel antibiotics. Different generalized and advanced methods have been adopted to isolate rare actinomycetes from various sources like soil, marine and plant. These methods include pretreatment, enrichment, antibiotics, membrane filter, different media compositions and integration for isolation of novel genera of the actinomycetes from soil. Marine and endophytic actinomycetes were explored in search of unexplored actinomycetes to find novel bioactive substances. Isolation of rare actinomycetes is difficult using conventional isolation techniques and hence advanced techniques and high throughput screening techniques has been adopted for isolation. Different strategy has been used for isolation and screening of antibiotic producing actinomycetes from these sources has been mentioned in this review. These methods can provide significant impetus towards the isolation and screening of novel actinomycetes which will be ultimately significant for discovery of antibiotics and other industrially important bioactive compounds.

\section{References}

Alferova, I., Terekhova, L., Prauzer, K. 1989. Selective medium with nalidixic acid for isolating antibioticproducing Actinomyces. Antibiot Khimioter, 34: 344-348.

Basavaraj, K., Nanjwade, S., Chandrashekhara, P., Goudanavar, S., Ali, M., Fakirappa, V. 2010. Production of antibiotics from Soilisolated actinomycetes and evaluation of their antimicrobial activities. Tropical J. Pharma. Res., 9: 373-377.
Bredholt, H., Fjaervik, E., Jhonsen, G., Zotechev, S.B. 2008. Actinomycetes from sediments in the Trondhein Fjrod, Norway: Diversity and biological activity. Mar Drugs, 6:1224.

Bull, A., Stach, J., Ward, A., Goodfellow, M. 2005. Marine actinobacteria: perspectives, challenges and future directions. Antonie van Leeuwenhoek, 87: 65-79.

Cao, L., Qiu, Z., You, J., Tan, H., Zhou, S. 2004. Isolation and characterization of endophytic Streptomyces strains from surface-sterilized tomato (Lycopersiconesculentum) roots. Appl. Microbiol., 39: 425-430.

Chiaki, I., Naoko, K., Masazumi, K,. Takeshi, K., Naoko, H. 2007. Actinomycetologica, 21:27-31.

Chiaki, I., Syunpei, M., Takeshi, K., Naoko, H., Takuji, N. 2010. Isolation and characterization of marine and terrestrial actinomycetes using a medium supplemented with $\mathrm{NaCl}$. Actinomycetologica, 24: 12-17

Connon, S., Giovannoni, S. 2002. Highthroughput methods for culturing microorganisms in very-low-nutrient media yield diverse new marine isolates. Appl. Environ. Microbiol., 68: 3878-3885.

Corbaz, R., Gregoby, P., Lacey, M. 1963. Thermophilic and mesophilie actinomycetes in mouldy hay. J. gen. Microbiol., 32: 449-456.

Corke, C., Chase, I. 1964. Comparative studies of actinomycete populations in acid podzolic and neutral mull forest soils. Soil Sei. SOC. Amer. Proc., 28: 68-70.

Crawford, D., Lynch, J., Whipps, J., Ousley, M. 1993. Isolation and characterization of actinomycete antagonists of a fungal root pathogen. 
Appl. Environ. Microbiol., 59: 38893905.

Cross, T. 1982. Actinomycetes: a continuing source of new metabolites. Dev. Indust. Microbiol., 23: 1-18.

Donadio, S., Carrano, L., Brandi, L., Serina, S., Soffientini, A., Raimondi, E., et al., 2002a. Targets and assay for discovering novel antibacterial agents. J. Biotechnol., 99:175-85.

Dulaney, E., Larsen, A., Stapley, E. 1955. A note on the isolation of microorganisms from natural sources. Mycologia, 47: 420-422.

El-Nakeeb, M., Lechevalier, H. 1963. Selective isolation of aerobic actinomycetes. Appl. Microbiol., 11: 75-77.

Goodfellow, M., Donnel, A. 1989. Search and discovery of industrially significant actinomycetes. In microbial products: New Approaches, Society for General Microbiology Symposium No. 44, ed. Baumberg, S., Hunter, I. S. and Rhodes, P. M. pp. 343-383. Cambridge: Cambridge University Press.

Hayakawa, M. 2008. Studies on the isolation and distribution of rare actinomycetes in soil. Actinomycetologica, 22:1219.

Hayakawa, M., Iino, H., Takeuchi, S., Yamazaki, T. 1997. Application of a method incorporating treatment with Chloramine-T for the selective isolation of Streptosporangiaceae from soil. J. Ferment. Bioeng., 84:599-602.

Hayakawa, M., Momose, Y., Kajiura, T., Yamazaki, T., Tamura, T., Hatano, K., Nonomura, H. 1995a. A selective isolation method for Actinomadura viridis in soil. J. Ferment. Bioeng., 79: 287-289.

Hayakawa, M., Momose, Y., Yamazaki, T., Nonomura, H. 1996b. A method for the selective isolation of Microtetrasporaglauca and related four-spored actinomycetes from soil. J. Appl. Bacteriol., 80: 375-386.

Hayakawa, M., Nonomura. H. 1989. A new method for the intensive isolation of actinomycetes from soil. Actinomycetol., 3: 95-104.

Hayakawa, M,. Otoguro, M,. Takeuchi, T., Yamazaki, T., Iimura, Y. 2000. Application of a method incorporating differential centrifugation for selective isolation of motile actinomycetes in soil and plant litter. Antonie Van Leeuwenhoek, 78: 171185.

Hayakawa, M., Sadakata, T., Kajiura, T., Nonomura, H. 1991a. New methods for the highly selective isolation of Micromonospora and Microbispora from soil. J. Ferment Bioeng., 72: 320-326.

Hayakawa, M., Tamura, T., Iino, H., Nonomura, H. 1991b. New methods for the highly selective isolation of Streptosporangium and Dactylosporangium from soil. $J$. Ferment. Bioeng., 72: 327-333.

Hayakawa, M., Tamura, T., Iino, H., Nonomura, H. 1991d. Pollen-baiting and drying method for highly selective isolation of Actinoplanes spp. from soil. J. Ferment. Bioeng., 72: 433-438.

Hayakawa, M., Tamura T, Nonomura, H. 1991c. Selective isolation of Actinoplanes and Dactylosporangium from soil by using collidine as the chemoattractant. J. Ferment. Bioeng., 72: 426-432.

Hayakawa, M., Yoshida, Y., Iimura, Y. 2004. Selective isolation of bioactive soil actinomycetes belonging to the Streptomyces violaceusniger phenotypic cluster. J. Appl. Microbiol., 96: 973-981. 
Hiroyasu, O., Yukiko, M., Yasuhiro, I., Tamotsu, F. 2011. Mycolic AcidContaining Bacteria Induce NaturalProduct Biosynthesis in Streptomyces Species. Appl. Environ. Microbiol., 77: 400-406.

Hirsch, C., Christensen, D. 1983. Novel Method for Selective Isolation of Actinomycetes. Appl. Environ. Microbiol., 46: 925-929.

Hong, K., Gao, A,. Xie, Q., Gao, H., Zhuang, L., Lin, H., Yu, H., Li, J., Yao, X., Goodfellow, M., Ruan, J. 2009. Actinomycetes for Marine Drug Discovery Isolated from Mangrove Soils and Plants in China. Mar. Drugs 7:24-44

Hopwood, D., Malpartida, F., Kieser, H., Duncan, I., Fujii, I., Rudd, B., Floss, H., Omura, S. 1985. Production of 'hybrid' antibiotics by genetic engineering. Nature, 314:642-644.

Indananda, C., Matsumoto, A., Inahashi, Y., Takahashi, Y., Duangmal, K., Thamchaipenet, A. 2011. Actinophyto-cola gen. nov., a new genus of the family Pseudonocardiaceae and description of a new species, Actinophytocoloa oryzae sp. nov., isolated from root of Thai jasmine rice plant. Int. J. Syst. Evol. Microbiol., 4:737-41.

Jinhua, Z. 2011. Improvement of an Isolation Medium for Actinomycetes, Modern Appl. Sci., 5:124-127.

Keller, M., Zengler, K. 2004. Tapping into microbial diversity. Nature Rev. Microbiol., 2: 141-150.

Kim, S., Goodfellow, M. 1999. Reclassification of Amycolatopsis rugosa Lechevalier et al., 1986 as Prauserella rugosa gen. nov., comb. nov. Int. J. Syst. Bacteriol., 49: 507512.

Kurtboke, D., Wilson, C., Sivasithamparam, K. 1993. Occurrence of Actinomadura phage in organic mulches used for avo-cado plantations in Western Australia. Can. J. Microbiol., 39: 389394.

Kuster, E., Williams, S. 1964. Selective media for the isolation of Streptomycetes. Nature 202: 928-929.

Lakshmipathy, D., Krishnan, K. 2010. Isolation and Characterization of Antagonistic Actinomycetes from Marine Soil. J. Microbial \& Biochem. Technol., 2: 001-006.

Lawrence, C. 1956. A method of isolating actinomycetes from scabby potato tissue and soil with minimal contamination. Can J. Bot., 34:44-47.

Linagarppa, Y., Lockwood, J. 1962. Chitin media for selective isolation and culture of actinomycetes. Phytopathol., 52: 317-323.

Lixiang, C., ZhiqiQ, Xin, D., Hongming, T., Yongcheng, L., Shining, Z. 2004. Isolation of endophytic actinomycetes from roots and leaves of banana (Musa acuminata) plants and their activities against Fusarium oxysporum sp. cubense. The world $J$. Microbiol. Biotechnol., 20: 501-504.

Magarvey, N.A., Keller, J.M., Bernan, V., Dworkin, M,. Sherman, D.H. 2004. Isolation and characterization of novel marine-derived actinomycete taxa rich in bioactive metabolites. Appl. Environ. Microbiol., 70:7520-9.

Masayuki, H., Emi, M., Youji, N., Yuzurulimura. 2007. A new enrichment method for the selective isolation of Streptomycetes from the root surfaces of Herbaceous plant. Actinomycetologica, 21:66-69.

Matsukawa, E., Nakagawa, Y., Iimura, Y,. Hayakawa, M. 2007b. A new enrichment method for the selective isolation of streptomycetes from the root surfaces of herbaceous plants. Actinomycetol., 21: 66-69. 
Matsukawa, E,. Nakagawa, Y., Iimura, Y., Hayakawa, M. 2007a. Stimulatory effect of indole-3-acetic acid on aerial mycelium formation and antibiotic production in Streptomyces spp. Actinomycetol., 21: 32-39.

Matsukawa, M., Nakagawa, Y., Limura, Y,. Hayakawa, M. 2007. A New Enrichment Method for the Selective Isolation of Streptomycetes from the Root Surfaces of Herbaceous Plants. Actinomycetologica, 21: 66-69.

McAlpine, J., Tuan, .J, Brown, D., Grebner, K., Whittern, .D, Buko, A., Katz, L. 1987. New antibiotics from genetically engineered actinomycetes. 2-Norerythromycins, isolation and structural determinations. J. Antibiot., 40: 115-122.

Mincer, T., Jensen, P., Kauffman, C,. Fenical, W. 2002. Widespread and persistent populations of a major new marine actinomycete taxon in ocean sediments. Appl. Environ. Microbiol., 68: 5005-5011.

Moran, M., Rutherford, L., Hodson, R. 1995. Evidence for Indigenous Streptomyces populations in a marine environment determined with a $16 \mathrm{~s} \mathrm{r}$ RNA probe. Appl. Environ. Microbiol., 61: 3695-3700.

Nonomura, H., Iino, S., Hayakawa, M. 1979. Classification of actinomycete genus Ampullariella from soils of Japan. J. Ferment. Technol., 57:7985.

Otoguro, M., Hayakawa, M., Yamazaki, T., Iimura, Y. 2001a. An integrated method for the selective isolation of Actinokineospora spp. in soil and plant litter. J. Appl. Bacteriol., 91: 118-130.

Otoguro, M., Hayakawa, M., Yamazaki, T., Tamura, T., Hatano, K., Iimura, Y. 2001b. Numerical phenetic and phylogenetic analyses of
Actinokineospora isolates, with a description of Actinokineospora auranticolor sp. nov. and Actinokineospora enzanensis sp. nov. Actinomycetol., 15: 30-39.

Parthasarathi, S., Sathya, S., Bupesh, G., Durai, R., Ram M, Selva K, Manikandan M, Kim C, Balakrishnan K 2012.Isolation and Characterization of Antimicrobial Compound from Marine Streptomyces hygroscopicus BDUS 49 World J. Fish and Marine Sci., 4(3):268-277.

Porter, J., Wilhelm, J,. Tresner, H. 1960. Method for the Preferential Isolation of Actinomycetes from Soils. Appl. Microbiol., 8:174-178.

Porter, J., Wilhelm, J., Tresner, H. 1960. Method for the preferential isolation of actinomycetes from soil. Appz. Microbiol., 8:174-178.

Rainey, F., Klatte, S., Kroppenstedt, R., Stackebrandt, E. 1995. Dietzia, a new genus including Dietzia maris comb. nov., formerly Rhodococcus maris. Int. J. Syst. Bacteriol., 45: 32-36.

Ravi Ranjan, K., Vasantba, J., Bhoomi, M., Bonisha, T.1., Bhumika, C. 2015. Antibacterial potentials of Actinomycetes isolated from Gujarat. Int. J. Pharm. Sci. Rev. Res., 30(1), 15: 78-83.

Seong, C., Choi, J,. Baik, K. 2001. An improved selective isolation of rare actinomycetes from forest soil. $J$. Microbiol., 17:23-39.

Siva, T.K., Umesh, K., Arjun, S. 2011. Isolation and screening of endophytic actinomycetes from different parts of Emblicaofficinalis. Annals of Biol. Res., 2(4):423-434.

Tamotsu, F., Yasuhiro, I., Takako, I., Tomomitsu, S., Noriko, S., Ryuji, Y. 2002. Isolation of Actinomycetes from Live Plants and Evaluation of Antiphytopathogenic Activity of 
Their Metabolites. Actinomycetol., 16: 9-13.

Tamura, T., Hayakawa, M., Hatano, K. 1997. A new genus of the order Actinomycetales, Spirilliplanes gen. nov., with description of Spirilliplane syamanashiensis sp. nov. Int. J.Syst. Bacteriol., 47:97-102.

Tamura, T., Hayakawa, M., Hatano, K. 1998. A new genus of the order Actinomycetales, Cryptosporangium gen. nov., with descriptions of Cryptosporangium arvum sp. nov. and Cryptosporangium japonicum sp. nov. Int. J. Syst. Bacteriol., 48: 9951005.

Tamura, T., Hayakawa, M., Hatano, K. 1999. Sporichthyabrevicatena sp. nov. Int. J. Syst. Bacterio., 49:1779-1784.

Tamura, T., Hayakawa, M., Nonomura, H., Yokota, A., Hatano, K. 1995. Four new species of the genus Actinokineospora: Actinokineospora inagensis sp. nov., Actinokineospora globicatena sp. nov., Actinokineospora terrae sp. nov., and Actinokineospora diospyrosa sp. nov. Int. J. Syst. Bacteriol., 45: 371-378.

Tsao, P., Leben, C., Keitt, G. 1960. An enrichment method for isolating actinomycetes that produce diffusible antifungal antibiotic. Pytopathol., 50:88-89.

Velho-Pereira, S., Kamat, N. 2010. Digital image analysis of actinomycetes colonies as a potential aid for rapid taxonomic identification. Nat Precedings. http://dx.doi.org/10.1038/ npre.2010.4209.1.

Yamamura, H., Hayakawa, M., Iimura, Y. 2003a. Application of sucrosegradient centrifugation for selective isolation of Nocardia spp. from soil. J. Appl. Microbiol., 95: 677-685.

Yamamura, H., Hayakawa, M., Nakagawa, Y., Iimura, Y. 2003b. Species diversity of Nocardiae isolated from Lake and Moat sediment samples. Actinomycetol., 17: 44-46.

Yasuhiro, I., Takako, I., Tomomitsu, S., Noriko, S., Ryuji, Y., Tamotsu, F. 2002. Isolation of actinomycetes from live plants and evaluation of antiphytopathogenic activity of their metabolites. Actinomycetol., 16: 9-13.

Yi, H., Schumann, P., Sohn, K,. Chun, J. 2004. Serinicoccus marinus gen. nov., sp. nov., a novel actinomycete with Lornithine and L-serine in the peptidoglycan. Int. J. Syst. Evol. Microbiol., 54: 1585-1589.

\section{How to cite this article:}

Ravi Ranjan Kumar and Vasantba J. Jadeja. 2016. Isolation of Actinomycetes: A Complete Approach. Int.J.Curr.Microbiol.App.Sci. 5(5): 606-618. doi: http://dx.doi.org/10.20546/ijcmas.2016.505.062 